ESJ Social Sciences

\title{
Resource Sustainability, Cooperation Risk Management Capacity and NPO Social Entrepreneurship Activity: A Conceptual Model
}

\author{
Kaoutar Erramy, PhD Student \\ Said Ahrouch, PhD
}

Faculty of Law, Economic and Social Sciences,

Ibn Zohr University, Agadir, Morocco

Doi:10.19044/esj.2021.v17n15p281

Submitted: 08 March 2021

Accepted: 21 May 2021

Published: 31 May 2021
Copyright 2021 Author(s)

Under Creative Commons BY-NC-ND

4.0 OPEN ACCESS

Cite As:

Erramy K. \& Ahrouch S. (2021). Resource Sustainability, Cooperation Risk Management Capacity and NPO Social Entrepreneurship Activity: A Conceptual Model.

European Scientific Journal, ESJ, 17(15), 281. https://doi.org/10.19044/esj.2021.v17n15p281

\section{Abstract}

Gaining knowledge about social entrepreneurship is important for nonprofit organizations to support their development process. Despite the different studies that treat social entrepreneurship, the role of the Cooperation Risk Management capacity in implementing a social entrepreneurial activity remains an unexplored research field. Scholars have paid particular attention to the capabilities that enable nonprofits to innovate and create social entrepreneurial activities. This paper aims to bridge resources' sustainability and social entrepreneurial activity. For so, social resource-based view theory is mobilized to present a conceptual model that highlights the indirect effect of nonprofit organization's resources sustainability through the mediation of cooperation risk management capacity. This paper sums up with potential implications for future empirical studies.

Keywords: Nonprofit Organization, Resource-Based View, Capabilities, Cooperation Risk Management Capacity, Social Entrepreneurship Activity

\section{Introduction}

An empirical study of over 200 Nonprofit Organizations (NPOs) has shown that the sustainability issue is one of their main concerns. Establishing 
new revenue-generating entrepreneurial activities makes $70 \%$ of these nonprofits operating in the social entrepreneurship zone (Di Zhang \& Swanson, 2013).

Furthermore, as new forms of social entrepreneurship are emerging in a context where public institutions, for-profit organizations, and non-profits interact, the risk inherent to the social entrepreneurship activity (SEA) remains a relevant topic. According to Macko \& Tyszka (2009), implementing a SEA is a risky decision to make. It is related to a significant degree of risk-taking compared to the implementation of other entrepreneurial activities. Since nonprofit's SEA process promotes cooperation between several stakeholders (Dees et al., 2002; Gras \& Mendoza-Abarca, 2014; Liu et al., 2015), the focus is on the potential mediation of Cooperation Risk Management (CRM) capacity to explain the resources sustainability effect on SEA implementation. In this regard, Chunlei et al. (2016) express that the non-profit organization maintains cooperative relationships with organizations when the cooperation risk is controlled to a minimum degree and thanks to the entrepreneurial team capabilities. These capabilities can be crucial in the social entrepreneurial process where financial risk and entrepreneurial risk intersect (Achibane \& Tlaty, 2018). Thus, an efficient NPO entrepreneurial risk management could be determinant for a good implementation of a SEA. It is notably in this perspective of the idea that we aim to identify the theoretical elements that contribute to a comprehensive understanding of our model. By using social Resource-Based View (RBV) we will explain and discuss the role of resources and organizational capabilities in the making of SEA. More specifically, the proposed conceptual model extends the SEA implementation model to include two constructs namely, resources sustainability and CRM capacity. The aim is to eliminate any confusion between the fields of social entrepreneurship and risk. This without forgetting to shed light on the economic risk related to cooperation.

A theoretical framework of the conceptual constructs is presented to explain the role of CRM capacity in the implementation of SEA. For so, SEA pillars and the capabilities required to form the CRM capacity and the main theoretical elements that describe the NPOs resource's sustainable nature are identified. That is to highlight the CRM capacity effects on SEA which needs sustainable resources for its implementation.

\section{What is social entrepreneurship?}

Social entrepreneurship consists of facing immediate social problems (Alvord et al., 2004). Creating and managing profit organizations or nonprofits and facing social problems by creating a systemic and sustainable social change through adopting new ideas, methods, and changing attitudes are the social entrepreneur missions (Kramer, 2005). 
Mair \& Martí, (2006) emphasize the innovative combination of resources. The importance of this innovative combination lies in its contribution as an innovative solution to the social problems facing society. Indeed, a simple change in the mix of nonprofits' resources can help generate the social impact that they set as an initial goal. Also, according to Austin et al. (2006), social entrepreneurship is an innovative activity that stimulates social value creation. It can occur within or through the non-profit, commercial, and government sectors. Sharir \& Lerner (2006) attribute to social entrepreneurship the purpose of implementing business strategies to deal with complex social problems for which policymakers have not found effective remedies. As Mair \& Martí (2006) gave to social entrepreneurship a definition that highlights the functional aspects while disregarding the institutional ones, Nicholls (2006) expresses that social entrepreneurship is occurring when individuals can use business techniques in some way to reach a positive social change.

Peredo \& McLean (2006) include the essential elements from the above definitions in their description. Their core idea focuses on innovative social value creation. It is about exploiting social opportunities that society offers by taking a higher level of risk than the norm. This risk-taking manifests itself in proposing revolutionary solutions to the complex social problems (Alvord et al., 2004; Defourny \& Nyssens, 2010b; Sharir \& Lerner, 2006). According to Peredo \& McLean (2006), the main concern in social entrepreneurship is to ensure the sustainability of the social enterprise, whatever will be the challenges it may eventually face. The definitions above, bring the answer to these questions: For whom? How? What? and why? And schematizes all that social entrepreneurship means. The figure below shows briefly the meaning of social entrepreneurship by answering the four questions.

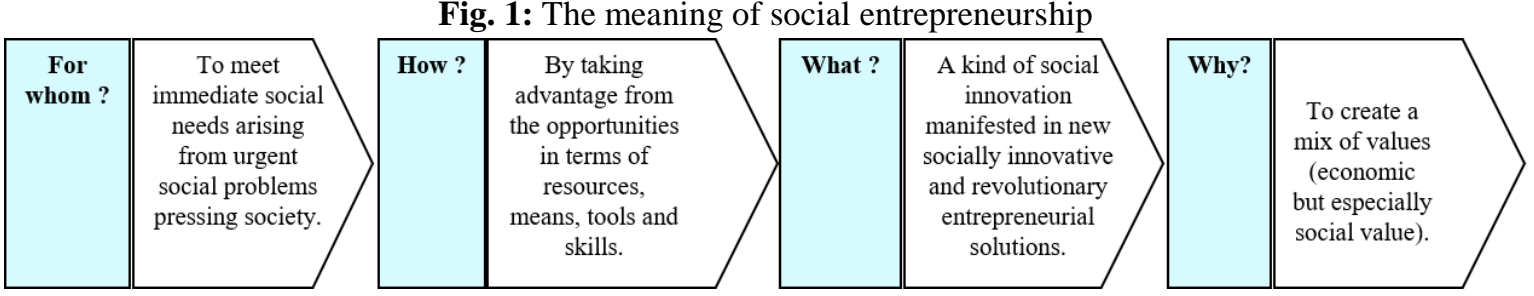

Source: Developed based on Alvord et al., 2004; Kramer, 2005; Mair \& Martí, 2006

\section{NPO social entrepreneurship: Definitions and pillars}

The social entrepreneurship concept emerged during the 1980s and it has become more present in recent years (Kamdem, 2016, p. 30). It has emerged as a way of expressing the dynamism of people who combine social activism and entrepreneurial skills. People who can see what others do not see, who can value what others are not enabled to value and who can manage while 
others cannot. Social entrepreneurship is about taking opportunities from social needs and satisfying them through innovative entrepreneurial solutions (Braunerhjelm \& Hamilton, 2012, p. 12).

While entrepreneurship is a value proposition responding to a need expressed by the market for financial profit, social entrepreneurship is a value proposition meeting a social need expressed by a given population. Social entrepreneurship aims to respond to the identified needs of society. Anticipating and organizing actions to create significant social benefits for society through satisfying social needs is also the aim of enterprising nonprofits. The main objective is social welfare. Social needs that could be addressed by nonprofits social entrepreneurship may include prevention against social ills, such as suicide, violence, sexual abuse, and drug addiction. Taking care of abandoned children and social integration of people with disabilities, as well as social assistance for people who have experienced separation or divorce, are all social needs that can be met through NPOs social entrepreneurship activities. In the following lines, NPO's SEA and its five pillars will be addressed.

\section{NPO social entrepreneurship activity}

Social entrepreneurship is about creating a movement of force that generates social change. This is done by taking the risk of using entrepreneurial technics to transform the change into a real impact on society. Entrepreneurial technics are used as tools to generate incomes to reinvest them in the social impact sustainability. It is a process of creating social value, bringing social change through direct action such as social transformation, social benefit, and also economic value namely wealth and employment. It is thus an entrepreneurial process of discovering, evaluating, and exploiting opportunities. This process encompasses the mobilization and allocation of funding, materials, and human resources (manpower and skills). An allocation that must have a positive impact on society through an innovative response to a detected social need. The importance of social entrepreneurship lies in proposing revolutionary responses to urgent and complex social problems (Alvord et al., 2004; Defourny \& Nyssens, 2010a; Sharir \& Lerner, 2006). Also, it lies in the fact that it carries out a central, purely social mission, which is the creation of social value-added. In social entrepreneurship, the capacity of creative thinkers that characterizes this emerging entrepreneurial approach serves to push other activists as stakeholders to involve and exercise social entrepreneurship through alternative organizational structures, such as forprofit social enterprises, non-profit organizations, and other social enterprises.

For these reasons, the implementation of SEA is an entrepreneurial adventure in which the actor is a catalyst of socio-economic development. Social entrepreneurship actors combine street activism, pragmatism, 
professional skills, and tactical trust to achieve public interest objectives. These actors often try to bring solutions to the negative externalities of the capitalist system in an entrepreneurial firm. Massarsky (2006) refers to social entrepreneurship as any commercial activity that emerges from the social actor's desire to create a social initiative to be able to generate revenues. This will enable any social actor such as non-profits to achieve their social goals. Nevertheless, creating commercial activities by non-profit organizations that lack financial resources and aiming to implement social projects is not that easy without collaborating with institutions such as public, private, or other NPOs.

Thus, NPOs' social entrepreneurial activities are an ethical optimization of every tool and resource to participate sustainably in social welfare. So, each revolutionary social response proposed, in an entrepreneurial way, for an urgent social problem is considered as part of this emerging entrepreneurial field. The economic risk associated with this venture is characterized by a high intensity due to the innovative nature of the social intervention. An intervention that consists of ideas, capabilities, and resource mobilization allows a social sustainable transformation through social arrangements. As every undertaking decision implies a risk-taking degree (Macko \& Tyszka, 2009), the decision of engaging in cooperation relationships to implement SEA is also a risky decision to make.

\section{The risky nature of the NPO social entrepreneurship process}

Social entrepreneurship is a succession of innovative use of available resource steps when seeking to exploit social opportunities. The objective is to create added value to improve the social situation of a given population in need. It is a process in which cooperation can be an innovative tool for sharing and using resources.

In all social entrepreneurship steps, social actors are exposed to the economic risk inherent to cooperation. The steps require a significant degree of risk-taking compared to cooperation for other traditional entrepreneurial activities' implementation. This is due to the complexity of the cooperation risk factors inherent to social entrepreneurship. The economic riskcooperation can occur when non-achieving the social objective is already fixed. When risk-cooperation is not enough controlled, the consequences may attain the collaborators' interest and the organization's reputation. Moreover, the consequences may contribute to the activity declining or ending. The process of implementing SEA does not lack economic risk. The triggering factors of this risk depend on several elements such as:

- A misunderstanding of the social problem, its constraints, and the heavy cost of the proposed solution; 
- Lack of flexibility in hierarchical structures due to bureaucratization, lack or inadequacy of funding, or the time lag between timeframes are other factors that can hinder the process of implementing SEA;

- Lack of a common indicators vocabulary of measuring social impact and the contribution of each actor to its creation;

- The discrepancy between the different requirements of actors that create a culture shock in cooperative work;

- Absence of convergence points ;

- Discontinuity in stakeholders' commitment.

To sum up, although business disruption, the loss of the institution's image, and the loss of employees could be the consequences of one of the triggering factors of cooperation risk mentioned above, the implementation of the NPO's SEA requires building various capabilities to manage this risk. Thus, the importance of CRM capacity.

\section{Cooperation Risk Management capacity}

Strengthening the CRM capacity is the organizational concern of every institution and also is the case for NPOs. Knowing how to manage cooperation risk factors or how to adapt with them empower the control of the cooperation risk. We are using the expression CRM capacity to refer to the ability of the organization to deal with the consequences of the cooperation risk occurrence. The Social Research-Based-View (SRBV) theory stressed the role of the dynamic capabilities of an institution (Da Silva \& Bitencourt, 2018). It states that dynamic capabilities depend on the origin and sustainable nature of the resources accumulated and exploited to acquire and develop these capabilities. So, to counteract the cooperation risk factors, it is necessary to take advantage of the sustainability and stability of resources to develop the quality of the three kinds of capital: social, political, and entrepreneurial. The cooperation risk control allows a healthy cooperative relationship with all the NPOs' stakeholders. Thus, the more NPOs are based on sustainable resources, the higher is their capacity to manage the cooperation risk.

\section{Entrepreneurial capabilities}

In an increasingly competitive market, social enterprises are now considered as entities competing with other business counterparts competing for survival and growth.

As is the case for commercial enterprises, non-profits are also under the obligation of using innovative entrepreneurial practices. Outperforming their main rivals requires NPOs to pursue strategies that aim to create significant social value for the benefit of their various stakeholders. For these reasons, the community actors must be formed in entrepreneurship and be 
supported to develop their capabilities to undertake more projects. This development process may lead to the constitution of entrepreneurial capital. Forming entrepreneurial capital requires the enhancement of capabilities that enable strategic social intelligence, creating and prototyping, building and maintaining quality relationships, and revenue generation. During the design and implementation phase, a high level of risk tolerance in decision-making is also a key factor in building capabilities. These elements should be taken as important in the implementation of SEA.

Firstly, one of the key capabilities is the ability to monitor and learn from market changes. Monitoring changes affecting the communities' social needs promotes the strategic development of NPO's activities. Strategic social intelligence capability is an important determinant of effectiveness and efficiency in terms of achieving social objectives. The higher the quality of this capability is, the more it contributes to the development of NPO's entrepreneurial capital.

Secondly, the design approach has proven worthwhile in innovation for social entrepreneurship. It is an approach based on a user-centered perspective and stakeholder involvement. This is achieved through participatory design and rapid prototyping. Prototyping reveals both opportunities and dilemmas (Hillgren, Seravalli, \& Emilson, 2011, p. 170). Its strengths lie in the fact that it is a visualization technic that supports the involvement of various stakeholders in the process. Being user-centric, prototyping complements the failure of the 'top-down' approaches (Mubita et al., 2017) and enables the new models' rapid testing in practice.

Thirdly, building and forging quality relationships is also a key capability for the development of entrepreneurial capital. The results of a survey carried out on a representative sample of 225 NPOs with a social mission, reveal that close relationships based on commitment and trust promote the development of social entrepreneurship innovations in NPOs (Sanzo et al., 2015). This effect depends on the nature of the organizations' contribution to these cooperating relationships and on their ability to make the collaboration a successful one. Social cooperation entrepreneurial issues are then manageable when relationships are based on trust as a resource and entrepreneurial commitment as an ability.

Fourthly, NPOs make great efforts and suffer while seeking funds to finance their activities (Di Zhang \& Swanson, 2013; Doherty et al., 2014; Kickul \& Lyons, 2015). Many difficulties are controverting them from attracting funds through traditional sources such as loans (Weerawardena \& Mort, 2006). Therefore, NPOs focusing on the development of their strategy must strengthen their ability to generate revenues (Bacq \& Eddleston, 2016) by developing and exploiting their sense of creativity. It has been shown that the ability to generate revenues in excess from expenses is important to the 
development of a business model (Dart, 2004) and allows the revenuesgenerating segment to finance the NPO's social activities (Boschee, 2001). As a result, they develop the ability to become "financially self-sufficient" (Boschee, 1998, p. 3) and less dependent on government and donations (Bacq \& Eddleston, 2016, p.6). Indeed, revenues can be directly generated from beneficiaries, as in the case of fee-for-service (Ebrahim et al., 2014) or in the case of Better-off-customers, where consumers seek to support charitable services (Bacq \& Eddleston, 2016).

Finally, every entrepreneurial field implies a certain degree of risktaking because creating something new is a risky entrepreneurial decision. However, the risk is even more intense in social entrepreneurship than in traditional entrepreneurship. According to Smith et al. (2014), this is because it is more likely to risk personal credibility than financial resources. NPOs leaders are individuals with a significant level of personal credibility (Dorado, 2006). Since it is systematically aligned with personal credibility, the organization's credibility stems from its strengths from the know-how and skills developed by leaders. It also stems its strengths from its leaders' integrity and ability to demonstrate their qualifications to stakeholders. The higher is the NPOs' risk tolerance, the more is the entrepreneurial capital.

Components such as skills and knowledge and the ability to assert their advantages to others are what define the credibility created among stakeholders. Therefore, social capital development is important for reinforcing relationships with stakeholders which can be possible through social capabilities enhancement.

\section{Social capabilities}

NPOs can aim to extend their social impact. Their mission is not only about producing goods or social services supply but about building strong social relationships. They are based on specific capabilities, such as their ability to attract support from various stakeholders, namely clients, clientbeneficiaries, suppliers, donors, and local social actors (Bacq \& Eddleston, 2016). Therefore, social capital is considered as "an entrepreneurial outcome" of the social entrepreneur efforts" (Thompson, 2002, p. 426)

NPOs are rooted in the social economy which, according to Fourel (2001) means not only the active participation of actors within their organization but also in the social life of the organization by using and reinforcing specific capabilities. Capabilities that require developing social capital by deploying social marketing strategies. This is through advertising and communicating about the targeted social impact. In the same way, there are two levels of analysis. The first level where the different relational capitals are federated and optimized to contribute to the creation of individual goods, and the second level of collective order, qualified as social capital. The latter 
is considered as the social entrepreneurship activity's social implications (Van Ryzin et al., 2009). It refers to the ability to communicate effectively and interact with donors, beneficiaries, clients, and communities (Lumpkin et al., 2013). This with or without involving the latter in the production of the collective good (Boncler \& Rispal, 2004, p. 24). Indeed, social capital development can be attained through the deployment of capabilities related to the strengthening of social cooperation relations. Social capabilities help strengthen the quality of the social capital developed by the NPOs. As a result, the organization gains more credibility with its various stakeholders. For instance, this is possible through communication and good cooperation with donors, customers and customers-beneficiaries (in the case of fee-for-service operations), beneficiaries and customers (in the case of better-off-customers operations) as well as with the entire community. The power of credibility lies not only in the fact that it facilitates the acquisition of resources within the cooperation network (Dees et al., 2002) but in the fact that it can also help the organization move beyond the immediate social cooperation network and find new opportunities.

Social capital aims to facilitate the design of a specific collective good benefiting a community that seeks a common need satisfaction. Social capital is a resource whose quality depends on the nature of interpersonal and interorganizational ties that lies between the different actors. This reveals the importance of the organization's credible image among all stakeholders. The organization's credibility is recognized as a precious immaterial asset that can be negatively affected by marketing strategies that are insufficiently studied (Jiao, 2011). It is an intangible resource that forms the social capital of every social NPO. It helps to attract requisite resources in the most favorable way (Dees et al., 2002).

As an essential partner, the social organization must also have credibility with the government. Hence, the importance of developing political capital through political capabilities.

\section{Political capabilities}

Various researchers argued that organizations engaged in social entrepreneurship activities need to strengthen their political capital (Bacq \& Eddleston, 2016; Bloom \& Smith, 2010; Santos, 2012).

Many authors have associated political resources with ResourceBased-View Theory (RBV). It recognizes that government support is important as a key resource for any organization's success. When economic success is influenced by public relations or controlled by the government, political capital can lead to economic benefits for an organization that aims to reach its goals (Frynas, Mellahi, \& Pigman, 2006, p. 341). Thus, this theory recognizes how government support affects organizations in terms of 
effectiveness and efficiency (Boddewyn \& Brewer, 1994; Frynas et al., 2006). It states that organizations' social initiatives can also benefit from cooperation with the government and gain legitimacy (Meyskens et al., 2010). Zahra, Newey \& Li (2014) have shown the importance of cooperation with the government to increase social impact and ensure social efficiency (Adeniran \& Johnston, 2012; Bacq \& Eddleston, 2016). That is why NPOs must build their own political capital. Different activities contribute to the construction of political capital, including lobbying and advocacy in form of courts for social change (Bacq \& Eddleston, 2016) and public relations. Frynas et al. (2006) describe government attributes as tools to enhance SEA to improve social and economic performance.

Again, the RBV argues that exclusive benefits related to the development of political capital are offered to organizations with social entrepreneurial activities whose access to resources is difficult. Di Domenico, Haugh \& Tracey (2010) stipulate that through political activities, NPOs can influence political agendas and convince legislators that their mission is for the benefit of the community. Lack of government support could limit the ability of NPOs to realize benefits and prevent social problems in society (Santos, 2012). The same logic for the NPOs that cannot attract government support. They are confronted with limitations that can deprive them of achieving their social objectives (Renko, 2013; Zahra et al., 2014). Developing public or political relations and advocacy skills is one of the important capacities for attracting state support and assistance (Adeniran \& Johnston, 2012; Bacq \& Eddleston, 2016). Political activities allow NPOs to communicate the community needs to the government and, consequently, to gain its assistance for realizing their social mission. In other words, through advocacy and lobbying, NPOs change political decisions. They highlight the social needs of the population and persuade political decision-makers that their mission will serve the community. As a result, NPOs can be able to take advantage of legal changes that help them to generate the social impact (Bacq \& Eddleston, 2016) they desire. This is through the implementation of social entrepreneurship projects or activities.

The political capital can be developed through lobbying. It is one of the political activities that enable NPOs to exert pressure on states. Valéau \& Boncler (2012) stipulate that NPOs must seize the opportunity offered to them and target social needs that the states fail to meet. It is a way to attract the government support they need to carry out their social mission (Santos, 2012). To attract government support, NPOs also advocate bringing the desires and expectations of communities to the attention of political decision-makers (London, 2008). Indeed, government assistance facilitates the legitimacy of NPOs to ensure the continuity of their mission (Zahra et al., 2014). It contributes to increasing social impact by facilitating the process of 
implementing social innovation. So, government regulations may increase the NPO's social impact level. This can be achieved through the contribution of government regulations on the social innovation quality level (Weber et al., 2012). In contexts where public policies reveal the growing importance of social innovation in society (Rollin \& Vincent, 2007, p. 13), social innovation is recognized as a key element in the realization of SEA. These reasons have led researchers to recognize the importance of developing political capital for the emergence of social organizations (Bloom \& Smith, 2010; Santos, 2012). Political support can be manifested as supporting legislations, laws, greater visibility of the social mission on the government's agenda or even financial assistance. Given the financial difficulties faced by NPOs, government support remains a necessity (Bacq \& Eddleston, 2016). For the same reason, stakeholders' involvement is in the social innovation process leading to good SEA implementation. We assume that the nonprofits' ability to control risk factors can be identified based on the company's history and its rivals' experience.

All the previous organizational capabilities together define another type of resource from the second generation: The CRM capacity.

Fig. 2: From organizational capabilities to CRM capacity

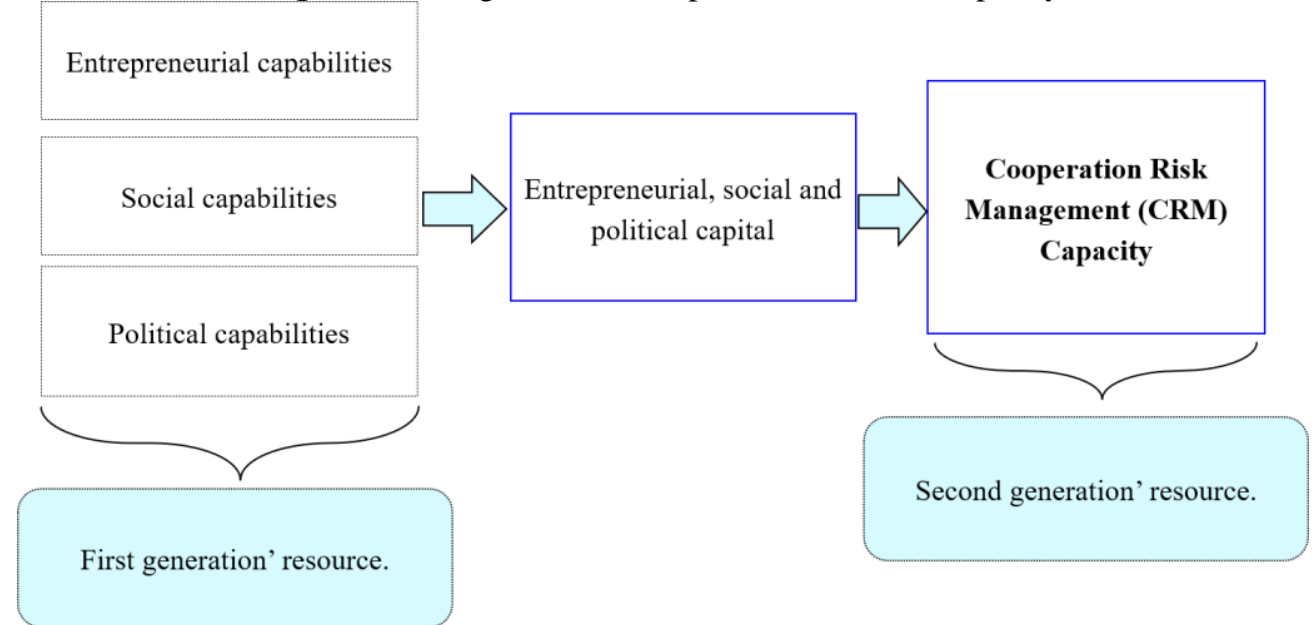

Source: Developed based on Adeniran \& Johnston, 2012; Bacq \& Eddleston, 2016.

\section{Resource sustainability}

Tension will always occur between pursuing opportunities providing resources to sustain the undertaking initiative and doing businesses creating social value with no substantial sources of revenue to cover expenses. An opportunity "could gain feasibility over time as conditions change or resources become accessible from different investors" (Dees et al., 2002, p. 57). When assessing a social opportunity as well as a traditional one, it may lead to good social value but does not have necessarily high sustainability 
potential. Dees et al. (2002) stress that "In the absence of program or service endowments or government contracts there are few options for addressing long term sustainability potential" (p.13). In this perspective, social entrepreneurship is about seeking to innovate new manners to get sustainable revenues to respond to the social problems of society.

Organizational forms requiring scarcer resources, for which acquisition is more uncertain, would have more problems sustaining activities than those requiring more stable and abundant resources (Pfeffer \& Salancik, 2003, p. 47). With this in mind, Moizer \& Tracey (2010) stressed that "Sustainability should be an overriding objective for any kind of organization; but for social enterprise, it takes on particular importance because of the uncertain and complex nature of their operating environment (Austin et al., 2006). Indeed, this variable acts as a barometer for the overall health of the organization" (p. 259). As nonprofits rarely have a research and development budget (Dees et al., 2002, p.13) the small ones are unable to engage in a longterm strategy. For instance, financial limitations can be crucial for paid staff recruitment (United Nations, 2003, p. 259).

Indeed, the mobilization of sustainable resources (Grant, 1991) can be favorable for the development of the NPOs' SEA because it may allow a continuous satisfaction of the community's social needs. Therefore, the funding of nonprofits is decisive for developing their activities. Furthermore, it guarantees the possibility of having better NPOs' social relationships with stakeholders. Nyssens (2006) states that the development of sustainable and direct contact with public authorities is often crucial to sustaining such activities in the long term. This especially when funding from a single source may deplete. In their book "The external control of organizations: A Resource Dependence Perspective" Pfeffer \& Salancik (2003) explain that the reason for organizations' problems, including NPOs, lies in the fact that resources emerge from their environment. Different studies have shown that the implementation of NPOs' SEA is positively related to the sustainability of resources (Bacq \& Eddleston, 2016; Di Zhang \& Swanson, 2013; Meyskens et al., 2010; Renko, 2013). Having sustainable resources can contribute to the teams' skills enhancement and an entrepreneurial social work process based mainly on managerial practices. Practices that converge towards new social business models with stakeholders' involvement to achieve the targeted social aims (Snow et al., 2008). We distinguish three resources' origins to describe the sustainable nature of NPOs' resources. As Moizer \& Tracey (2010) stressed, NPOs can rely on the membership fees and their financial business segments revenues. Government subsidies coming from suggested social projects can also be a source of sustainable resources as well as philanthropy in the form of donations and volunteering. 


\section{The proposed conceptual model}

Different studies have shown that the SEA, and particularly the NPOs' SEA, is being positively related to their sustainable resources purchased (Moizer \& Tracey, 2010). As a result, it appears that the implementation of SEA of NPOs exploiting different funding sources can be better when disposing of sustainable resources.

$\mathbf{P}_{1}$ : The NPO resources sustainability has a positive effect on SEA implementation.

The NPO is seen as an incubator for social entrepreneurship practice. It is seen as an accelerating model of the social innovation process. Managerial solutions from the for-profit sector are adopted to gain sustainability and legitimacy. It innovates new ways of doing things, including cooperating with other stakeholders to share resources, knowledge, and risk (De Winne \& Sels, 2010; Erikson, 2002) as benefits. These benefits promote the institution's sustainability. Resources are an indispensable element for the existence and sustainability of any entrepreneurial activity and even more in the social entrepreneurship field.

The NPOs resources' sustainability has a positive influence on its capacity to manage cooperation risk. It allows the improvement of NPO's SEA implementation level since it is considered as a second generation' resource that favors the development of the institution's political, social, and entrepreneurial capital quality. Consequently, it is expected that the capacity to manage risk is essential for explaining a better implementation of the NPO's SEA in cooperative relationships. Therefore, we suggest the following propositions:

P2.1: Sustainable resources had a positive effect on CRM capacity.

P2.2: CRM capacity has a positive effect on NPOs' SEA implementation.

Largely cited in the literature as a crucial element in the implementation of SEA, it appears that managing cooperation risk is a determinant factor. It affects NPOs that exploit several origins of resources. A certain degree of CRM capacity then proves a decisive condition for SEA implementation. Hence, the proposal of the mediating effect of the CRM capacity.

P3: The relationship between resource sustainability and NPO's SEA is mediated by CRM capacity.

As the good capacity to face stakeholder's cooperation constraints depends on resource origin, NPOs are likely to show different categories of capabilities. In this paper, we are interested in three types of capabilities. Each of them has its specific functions and contexts of use (Bhatt \& Altinay, 2013; Liu et al., 2015; Mair \& Noboa, 2006; Mort et al., 2003; Rodrigo-Alarcón et al., 2018). 
Fig. 3: The proposed conceptual model

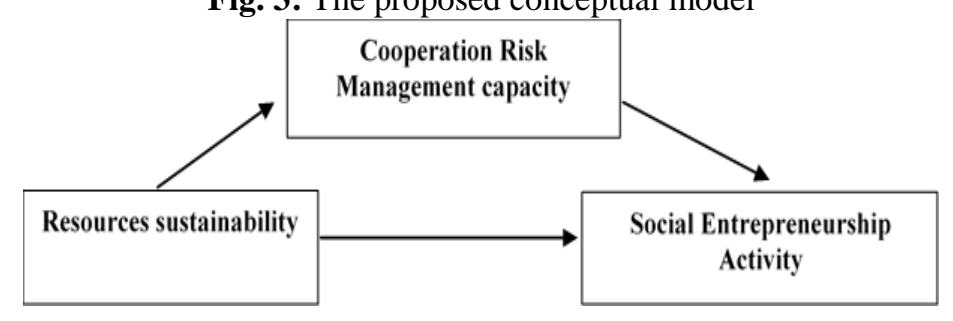

\section{Conclusion}

By exploring how the resources' sustainability may explain the extent of SEA, the present conceptual research shows that this relationship is an indirect one. This is due to the capabilities' diversification that NPOs require as a mediator for implementing SEA. A good capacity to manage cooperation risk may be sufficient for a strong cooperating relationship. They can be considered as strongly affecting the capacity to manage the cooperation risk triggering factors.

\section{Theoretical contributions}

This research paper aims to highlight the emerging movement of enterprising nonprofits. This is by advancing research about how NPOs seek to cooperate to implement SEA. As such, the paper highlights how entrepreneurial, social and political capabilities' enhancement can be strongly affecting factors on nonprofits' social entrepreneurship development. For example, while the theoretical contribution of Bacq \& Eddleston (2016) was in extending RBV theory to the social enterprise by developing it through the integration of stakeholders' interaction with the latter, the contribution of this research is that it extends the RBV theory to NPOs SEA by integrating a second generation' resource namely CRM capacity.

\section{Managerial implications}

This research seems to have various managerial implications for future researchers and decision-makers for managing and developing nonprofits. It supplies insights about the importance of CRM capabilities under three forms social, political, and entrepreneurial. These are identified as scalers mediating the passage from resource supply to good SEA. Sustainable resources are critical conditions for the success of SEA. Nonprofits should invest in building capabilities as a way to develop the resources' supply conditions, in particular, for small NPOs with limited skills and resources. Exploring nonprofits' SEA from contexts geographically different can demonstrate the role of resources' sustainability and CRM capacity in SEA implementation. This is by exploiting the moderator effects analyzed from the research. The present conceptual research provides a fundamental basis for future empirical studies which 
present a shortcoming of this paper to validate the conceptual model. Social entrepreneurship can embrace all the different approaches that can be adopted to develop and manage nonprofit institutions, namely Associations (Valéau \& Boncler, 2012). They can eventually be the subject of analysis in future empirical studies.

\section{References:}

1. Achibane, M., \& Tlaty, J. (2018). The entrepreneurial finance and the issue of funding startup companies. European Scientific Journal, 14(13), 268-279.

2. Adeniran, T. V, \& Johnston, K. A. (2012). Investigating the dynamic capabilities and competitive advantage of South African SMEs. African Journal of Business Management, 6(11), 4088-4099.

3. Alvord, S. H., Brown, L. D., \& Letts, C. W. (2004). Social Entrepreneurship and Societal Transformation: An Exploratory Study. The Journal of Applied Behavioral Science, 40(3), 260-282. https://doi.org/10.1177/0021886304266847

4. Austin, J., Stevenson, H., \& Wei-Skillern, J. (2006). Social and commercial entrepreneurship: Same, different, or both? Entrepreneurship: Theory and Practice, 30(1), 1-22. https://doi.org/10.1111/j.1540-6520.2006.00107.x

5. Bacq, S., \& Eddleston, K. A. (2016). A Resource-Based View of Social Entrepreneurship: How Stewardship Culture Benefits Scale of Social Impact. Journal of Business Ethics, 152(3), 589-611. https://doi.org/10.1007/s10551-016-3317-1

6. Bhatt, P., \& Altinay, L. (2013). How social capital is leveraged in social innovations under resource constraints? Management Decision, 51(9), 1772-1792. https://doi.org/10.1108/MD-01-2013-0041

7. Bloom, P. N., \& Smith, B. R. (2010). Identifying the drivers of social entrepreneurial impact: Theoretical development and an exploratory empirical test of SCALERS. Journal of Social Entrepreneurship, 1(1), 126-145. https://doi.org/10.1080/19420670903458042

8. Boddewyn, J. J., \& Brewer, T. L. (1994). International-business political behavior: New theoretical directions. Academy of management review, 19(1), 119-143.

9. Boncler, J., \& Rispal, M. H. (2004). L'entrepreneuriat en milieu solidaire : un phénomène singulier ? Revue de l'Entrepreneuriat, 3(1), 21. https://doi.org/10.3917/entre.031.0021

10. Boschee, J. (1998). Merging Mission and Money: A Board Member's Guide to Social Entrepreneurship. The National Center for Nonprofit Boards, 1-12.

11. Boschee, J. (2001). Eight basic principles for nonprofit entrepreneurs. 
Nonprofit World, 19(4), 15-18.

12. Braunerhjelm, P., \& Hamilton, U. S. (2012). Social entrepreneurship a survey of current research. In Swedish Entrepreneurship Forum (Numéro 09).

13. Chunlei, W., Zhaowen, D., \& Larry, Y. (2016). From nonprofit organization to social enterprise: The paths and future of a Chinese social enterprise in the tourism field. International Journal of Contemporary Hospitality Management, 28(6), 1287-1306. https://doi.org/10.1108/IJCHM-05-2014-0230

14. Da Silva, S. B., \& Bitencourt, C. C. (2018). Towards a SocialResource-Based View (SRBV). Mega Journal of Business Research, 2018.

15. Dart, R. (2004). Being "business-like" in a nonprofit organization: A grounded and inductive typology. Nonprofit and voluntary sector quarterly, 33(2), 290-310.

16. De Winne, S., \& Sels, L. (2010). Interrelationships between human capital, HRM and innovation in Belgian start-ups aiming at an innovation strategy. The International Journal of Human Resource Management, 21(11), 1863-1883.

17. Dees, J. G., Emerson, J., \& Economy, P. (2002). Enterprising nonprofits: A toolkit for social entrepreneurs (Vol. 186). John Wiley $\&$ Sons.

18. Defourny, J., \& Nyssens, M. (2010a). Conceptions of social enterprise and social entrepreneurship in Europe and the United States: Convergences and divergences. Journal of social entrepreneurship, $1(1), 32-53$.

19. Defourny, J., \& Nyssens, M. (2010b). Social enterprise in Europe: At the crossroads of market, public policies and third sector. Policy and Society, 29(3), 231-242. https://doi.org/10.1016/j.polsoc.2010.07.002

20. Di Domenico, M., Haugh, H., \& Tracey, P. (2010). Social bricolage: Theorizing social value creation in social enterprises. Entrepreneurship theory and practice, 34(4), 681-703.

21. Di Zhang, D., \& Swanson, L. A. (2013). Social entrepreneurship in nonprofit organizations: An empirical investigation of the synergy between social and business objectives. Journal of Nonprofit \& Public Sector Marketing, 25(1), 105-125.

22. Doherty, B., Haugh, H., \& Lyon, F. (2014). Social enterprises as hybrid organizations: A review and research agenda. International journal of management reviews, 16(4), 417-436.

23. Dorado, S. (2006). Social entrepreneurial ventures: different values so different process of creation, no? Journal of developmental entrepreneurship, 11(04), 319-343. 
24. Ebrahim, A., Battilana, J., \& Mair, J. (2014). The governance of social enterprises: Mission drift and accountability challenges in hybrid organizations. Research in Organizational Behavior, 34, 81-100.

25. Erikson, T. (2002). Entrepreneurial capital: the emerging venture's most important asset and competitive advantage. Journal of business venturing, 17(3), 275-290.

26. Fourel, C. (2001). Le goût des autres et le capital social: les enjeux de la nouvelle économie sociale. La nouvelle économie sociale, efficacité, solidarité, démocratie, sous la direction de C. Fourel, Paris: Syros.

27. Frynas, J. G., Mellahi, K., \& Pigman, G. A. (2006). First mover advantages in international business and firm-specific political resources. Strategic Management Journal, 27(4), 321-345.

28. Grant, R. M. (1991). The resource-based theory of competitive advantage: implications for strategy formulation. California management review, 33(3), 114-135.

29. Gras, D., \& Mendoza-Abarca, K. I. (2014). Risky business? The survival implications of exploiting commercial opportunities by nonprofits. Journal of Business Venturing, 29(3), 392-404. https://doi.org/10.1016/j.jbusvent.2013.05.003

30. Hillgren, P. A., Seravalli, A., \& Emilson, A. (2011). Prototyping and infrastructuring in design for social innovation. CoDesign, 7(3-4), 169-183. https://doi.org/10.1080/15710882.2011.630474

31. Jiao, H. (2011). A conceptual model for social entrepreneurship directed toward social impact on society. Social Enterprise Journal, 7(2), 130-149. https://doi.org/10.1108/17508611111156600

32. Kamdem, E. (2016). Innovation entrepreneuriale et développement durable en Afrique : défis et opportunités. Editions L'Harmattan.

33. Kickul, J., \& Lyons, T. S. (2015). Financing social enterprises. Entrepreneurship Research Journal, 5(2), 83-85.

34. Kramer, M. R. (2005). Measuring innovation: Evaluation in the field of social entrepreneurship. Skoll Foundation, Boston, MA: Foundation Strategy Group.

35. Liu, G., Eng, T., \& Takeda, S. (2015). An investigation of marketing capabilities and social enterprise performance in the UK and Japan. Entrepreneurship Theory and Practice, 39(2), 267-298.

36. London, T. (2008). The base-of-the-pyramid perspective: A new approach to poverty alleviation. Academy of management proceedings, 2008(1), 1-6.

37. Lumpkin, G. T., Moss, T. W., Gras, D. M., Kato, S., \& Amezcua, A. S. (2013). Entrepreneurial processes in social contexts: How are they different, if at all? Small Business Economics. https://doi.org/10.1007/s11187-011-9399-3 
38. Macko, A., \& Tyszka, T. (2009). Entrepreneurship and risk taking. Applied psychology, 58(3), 469-487.

39. Mair, J., \& Martí, I. (2006). Social entrepreneurship research: A source of explanation, prediction, and delight. Journal of World Business, 41(1), 36-44. https://doi.org/10.1016/j.jwb.2005.09.002

40. Mair, J., \& Noboa, E. (2006). Social entrepreneurship: How intentions to create a social venture are formed. Social entrepreneurship, 121-135.

41. Massarsky, C. W. (2006). Coming of age: Social enterprise reaches its tipping point. In Research on Social Enterpreneurship (p. 67-88).

42. Meyskens, M., Robb-Post, C., Stamp, J. A., Carsrud, A. L., \& Reynolds, P. D. (2010). Social ventures from a resource-based perspective: An exploratory study assessing global Ashoka fellows. Entrepreneurship theory and practice, 34(4), 661-680.

43. Moizer, J., \& Tracey, P. (2010). Strategy making in social enterprise: The role of resource allocation and its effects on organizational sustainability. Systems research and behavioral science, 27(3), 252-266.

44. Mort, G., Weerawardena, J., \& Carnegie, K. (2003). Social entrepreneurship: Towards conceptualisation. International Journal of Nonprofit and Voluntary Sector Marketing, 8(1), 76-88.

45. Mubita, A., Libati, M., \& Mulonda, M. (2017). The importance and limitations of participation in development projects and programmes. European scientific journal, 13(5), 238-251.

46. Nicholls, A. (2006). Social Entrepreneurship New Models of Sustainable Social Change.

47. Nyssens, M. (2006). Social enterprises at the crossroads of markets, public policies and civil society. In Routledge Studies in the Management of Voluntary and Non-Profit Organizations. https://doi.org/10.1007/s13398-014-0173-7.2

48. Peredo, A. M., \& McLean, M. (2006). Social entrepreneurship: A critical review of the concept. Journal of World Business, 41(1), 56-65. https://doi.org/https://doi.org/10.1016/j.jwb.2005.10.007

49. Pfeffer, J., \& Salancik, G. R. (2003). The external control of organizations: A resource dependence perspective. Stanford University Press.

50. Renko, M. (2013). Early challenges of nascent social entrepreneurs. Entrepreneurship: Theory and Practice, 37(5), 1045-1069. https://doi.org/10.1111/j.1540-6520.2012.00522.x

51. Rodrigo-Alarcón, J., García-Villaverde, P. M., Ruiz-Ortega, M. J., \& Parra-Requena, G. (2018). From social capital to entrepreneurial orientation: The mediating role of dynamic capabilities. European 


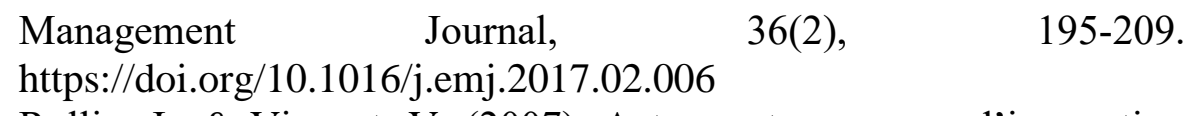

52. Rollin, J., \& Vincent, V. (2007). Acteurs et processus d'innovation sociale au Québec. Réseau québécois en innovation sociale.

53. Santos, F. M. (2012). A positive theory of social entrepreneurship. Journal of business ethics, 111(3), 335-351.

54. Sanzo, M. J., Álvarez, L. I., Rey, M., \& García, N. (2015). Businessnonprofit partnerships: a new form of collaboration in a corporate responsibility and social innovation context. Service Business, 9(4), 611-636. https://doi.org/10.1007/s11628-014-0242-1

55. Sharir, M., \& Lerner, M. (2006). Gauging the success of social ventures initiated by individual social entrepreneurs. Journal of world business, 41(1), 6-20.

56. Smith, R., Bell, R., \& Watts, H. (2014). Personality trait differences between traditional and social entrepreneurs. Social Enterprise Journal.

57. Snow, D. A., Soule, S. A., \& Kriesi, H. (2008). The Blackwell companion to social movements. John Wiley \& Sons.

58. Thompson, J. L. (2002). The world of the social entrepreneur. International journal of public sector management.

59. United Nations. (2003). Handbook on non-profit institutions in the system of national accounts: Vol. No. 91 (Numéro Series F). United Nations Publications.

60. Valéau, P., \& Boncler, J. (2012). Les acteurs du monde associatif face aux différentes propositions de l'entrepreneuriat social: du scepticisme à une adoption conditionnelle. RIMHE: Revue Interdisciplinaire Management, Homme Entreprise, 3, 17-35.

61. Van Ryzin, G. G., Grossman, S., DiPadova-Stocks, L., \& Bergrud, E. (2009). Portrait of the social entrepreneur: Statistical evidence from a US panel. Voluntas: International Journal of Voluntary and Nonprofit Organizations, 20(2), 129-140.

62. Weber, C., Kröger, A., \& Lambrich, K. (2012). Scaling social enterprises- A theoretically grounded framework. Frontiers of Entrepreneurship Research, 32(19).

63. Weerawardena, J., \& Mort, G. S. (2006). Investigating social entrepreneurship: A multidimensional model. Journal of world business, 41(1), 21-35.

64. Zahra, S. A., Newey, L. R., \& Li, Y. (2014). On the frontiers: The implications of social entrepreneurship for international entrepreneurship. Entrepreneurship theory and practice, 38(1), 137-158. 